\title{
"Já pensamos direto em espanhol": reflexões sobre a aprendizagem de espanhol através de produções escritas de discentes do ensino técnico
}

\author{
Antonio Ferreira da SILVA JÚNIOR (CEFET/RJ) ${ }^{1}$ \\ Priscila da Silva MARINHO (UFRJ) ${ }^{2}$
}

\section{Resumo}

estagiária em formação e corpo discente de uma escola tecnológica, localizada no Rio de Janeiro, em relação ao processo de aprendizagem do Espanhol. O foco da reflexão pauta-se em falas e produções escritas produzidas por alunos de Espanhol do 10 ano do Ensino Médio e geradas numa situação de avaliação bimestral. Quando levados a ponderar sobre sua aprendizagem e produção textual em Língua Espanhola, os alunos, em sua maioria, afirmam pensar diretamente em língua estrangeira (LE) para registrar seus textos. Em nossa análise dos dados, refletimos sobre como se figura uma relação entre a língua materna (LM) e a LE no processo de subjetividades do aprendiz. O estudo, assim, revela uma inconsistência entre o que os estudantes declaram saber e fazer em Espanhol e o que demonstram em suas produções escritas. Tomamos como referencial teórico para pensar a contribuição da LM na aprendizagem da LE os estudos de Serrani (1997), Revuz (1998), Celada (2004, 2008), Grigoletto (2010) e Celada e Payer (2016), além de algumas contribuições filosóficas de Bakhtin (2014). A experiência compartilhada nos leva a cogitar a necessidade de discussão e inserção da reflexão sobre o processo de aprendizagem na formação linguístico-discursiva de nossos alunos, sendo essa uma prática que pode contribuir para a não naturalização de certas crenças sobre o ensino de línguas na escola. Esperamos que o artigo também possibilite analisar a importância da aprendizagem do Espanhol no contexto da educação profissional e de seu ensino entre as opções de língua estrangeira da Educação Básica, propostas rechaçadas a partir da aprovação da Lei no 13.415/2017 (BRASIL, 2017).

Palavras-chave: Ensino-aprendizagem de línguas. Língua materna. Língua estrangeira. Espanhol. Produção escrita.

\section{Resumen}

En este artículo se propone investigar y exponer una reflexión teórica y práctica a partir de una experiencia compartida entre profesor regente, pasante en formación y cuerpo discente de una escuela tecnológica, ubicada en Río de Janeiro, con relación al proceso de aprendizaje del Español. El foco de nuestra discusión se basa en hablas y producciones escritas realizadas por alumnos de Español del $1^{\text {er }}$ año de la Enseñanza Secundaria y generadas en una situación de evaluación bimestral. Los alumnos, en su mayoría, afirman pensar directamente en Lengua Española al producir sus textos. En nuestro análisis de los datos, podemos observar una relación que se establece entre la lengua materna (LM) y la lengua extranjera (LE) en el proceso de subjetividades del aprendiz. El estudio, de este modo, revela una inconsistencia entre lo que los estudiantes declaran saber y hacer en Español y lo que demuestran en sus producciones escritas. Nuestro referencial teórico se basa desde perspectivas que piensan la contribución de la LM en el aprendizaje de la LE, como los estudios de Serrani (1997), Revuz (1998), Celada (2004, 2008), Grigoletto (2010) y Celada y Payer (2016), además de algunas contribuciones filosóficas de Bajtín (2014). La experiencia compartida nos impulsa a reflexionar sobre la necesidad de discusión e inserción de los procesos de aprendizaje en la formación lingüística y discursiva de nuestros alumnos. Creemos que tal práctica puede contribuir a la no naturalización de ciertas creencias hacia la enseñanza de lenguas en la escuela. Esperamos que el artículo también posibilite analizar la importancia del aprendizaje del Español en el contexto de la educación profesional y de su enseñanza entre las opciones de lengua extranjera en la Educación Básica, una vez que dichas propuestas se rechazaron tras la aprobación de la Ley no 13.415/2017 (BRASIL, 20017).

\footnotetext{
${ }^{1}$ Doutor em Letras Neolatinas (UFRJ) e Professor de Língua Espanhola do Cefet/Rj. E-mail: afjrespanhol@gmail.com

2Doutoranda em Letras Neolatinas (UFRJ) e Bolsista CNPq. E-mail: priscilasilvamarinho@globomail.com
} 
Palabras clave: Enseñanza y aprendizaje de lenguas. Lengua materna. Lengua extranjera. Español. Producción escrita.

\section{Introdução}

O objetivo deste artigo é promover uma reflexão sobre a aprendizagem de Espanhol por meio de excertos de falas narrativas e produções escritas de alunos de Ensino Médio de uma instituição tecnológica de ensino. Tais produções foram geradas na ocasião de uma prova bimestral sem nenhum tipo de consulta por discentes de uma turma de 10 ano de Ensino Médio do Centro Federal de Educação Tecnológica Celso Suckow da Fonseca (Cefet/Rj), campus Maracanã. Já as narrativas em áudio foram geradas após a finalização da avaliação escrita e visava compreender como os discentes comentam sobre suas aprendizagens. À época da pesquisa, realizada em 2011, os autores deste artigo se encontravam na função de professor regente e supervisor do campo de estágio e estagiária/professora em formação, respectivamente. A proposta desta pesquisa foi possível graças à colaboração e participação dos autores na investigação do contexto vivenciado.

A disciplina de Língua Espanhola no currículo do Cefet/Rj tinha por objetivo conscientizar o educando do papel social de aprender uma língua estrangeira (BRASIL, 2006) aliado ao desenvolvimento de práticas de linguagem por meio da apresentação, assimilação e produção de diferentes gêneros discursivos. As séries escolares do Ensino Médio tinham um foco, respectivamente, nas diferentes tipologias textuais: descrição, narração e argumentação e as aulas eram ministradas em Espanhol. Durante cada bimestre, os alunos eram apresentados a uma temática de natureza sociocultural e, pelo menos, dois gêneros discursivos com predomínio de certa tipologia textual. As produções orais e escritas dos gêneros utilizados como objeto de aprendizagem aconteciam em sala, em casa e/ou nas avaliações bimestrais. Cabe ressaltar que, desde 2014, no campus sede, a disciplina foi retirada do currículo escolar obrigatório por conta da implementação do Ensino Médio Integrado, cuja proposta se resume à articulação entre a formação propedêutica e a técnica em uma única matriz de formação. Após a exposição das propostas pedagógicas de cada 
disciplina de formação geral e técnica, os grupos de trabalho ponderavam sobre a aproximação e pertinência de tais disciplinas e conteúdos na formação profissional do futuro técnico. Com isso, a disciplina de Língua Espanhola obteve aprovação somente na matriz curricular do curso técnico de Turismo, sendo retirada dos demais cursos integrados. A alegação foi de que os alunos não demandariam da Língua Espanhola em sua atuação futura como técnicos em construção civil, eletrônica, telecomunicações, administração, por exemplo, somente para citar algumas carreiras. Acreditamos que essa mera visão de um ensino utilitarista e aplicado acaba sendo um dos riscos de uma proposta de Ensino Médio Integrado pouco discutida e sem perspectivas de uma formação mais integral do sujeito para agir socialmente.

A tentativa de oferta do Espanhol no formato de oficinas optativas, no referido campus, vigorou somente durante o ano de 2014, já que o próprio departamento de Ensino Médio e Técnico não contribuiu para a efetivação do projeto elaborado pelo corpo docente, que incluía oficinas temáticas sobre leitura, produção de gêneros discursivos, conversação, cinema e outros temas.

Para este artigo, nosso propósito foi examinar as redações discentes, geradas na situação já mencionada anteriormente - época em que a disciplina constava como obrigatória no currículo - analisando as relações entre o português e o Espanhol, procurando observar, assim, a influência que língua materna exerce no ensino/aprendizagem do Espanhol. Em suma, desejamos entender como o alunado concebe a língua estrangeira (LE), isto é, os imaginários que deixam vir à tona, como, por exemplo, a crença de que aprender uma LE é converter suas palavras as de sua LM. Em síntese, almejamos neste artigo propiciar considerações teórico-práticas no que tange às narrativas de ensino de Espanhol através da análise de produções escritas de discentes de 10 ano de Ensino Médio.

Para alcançar nossos objetivos, dividimos essa experiência didática em algumas seções, são elas: a presença e o papel do Espanhol no currículo do Cefet/Rj antes de sua retirada, a fundamentação teórica, a proposta metodológica, a análise dos dados e, por último, algumas considerações finais. 


\section{Um breve histórico da presença das línguas estrangeiras no Cefet/Rj}

Não existe uma data precisa de quando as línguas estrangeiras começaram a ser ofertadas na educação profissional. No cenário do Cefet/Rj, a primeira menção ao ensino de idiomas é fruto de uma parceria de internacionalização idealizada entre o Governo Brasileiro e os Estados Unidos para a capacitação de professores de todo o Brasil para o ensino industrial. Essa formação continuada de preparação para o intercâmbio nos Estados Unidos aconteceu na antiga Escola Técnica Nacional (hoje, Cefet/Rj), durou três meses e incluiu aulas de Língua Inglesa para os docentes. Essa primeira aparição do Inglês no referido contexto evidencia-se através do resgate histórico proposto por Ciavatta e Silveira (2010) em relação à atuação do educador Celso Suckow no cenário da educação profissional brasileira. De acordo com as pesquisadoras, o curso de Língua Inglesa "[...] dividia-se em duas etapas, sendo a primeira uma revisão dos conhecimentos gerais e técnicos e estudo da Língua Inglesa, e a segunda um curso de aperfeiçoamento nos Estados Unidos" (CIAVATTA; SILVEIRA, 2010, p. 30).

Tem-se nessa ação claramente o início de uma política de valorização da LE como porta de acesso a outros bens culturais e de parceria com instituições estrangeiras visando o intercâmbio de saberes. Por exemplo, em 1948, o Programa Fulbright, lançado pelos Estados Unidos, defendia que um ano de estudos num país considerado como potência aumentaria a compreensão internacional do participante (NORTE, 2014, p. 8).

Devido à junção de currículos entre a educação profissional e o segundo grau de formação geral - atualmente Ensino Médio - proposto pela LDB no 5.692/1971, a educação secundarista passou a ser técnica. Com isso, pela primeira vez na história, as LE, ou melhor, o Inglês, fez parte da formação do currículo do ensino profissional. Logo, é possível afirmar que o Inglês esteve presente como LE recomendada no Cefet/Rj, pelo menos, desde a aprovação de tal LDB. Durante muito tempo, acreditou-se que somente a Língua Inglesa seria a responsável por internacionalizar alunos e professores. Felizmente, o Cefet/Rj, no início dos anos 2000, abriu-se para o reconhecimento e valorização de uma política plurilíngue em suas ações acadêmicas. 
A disciplina de Espanhol insere-se na instituição devido à abertura do curso técnico de Turismo no ano de 2002, sendo essa área a primeira a se distanciar do campo quase predominante de cursos oriundos das áreas industriais e de exatas. Segundo Silva Júnior (2010), as línguas estrangeiras:

[...] eram ofertadas como disciplinas obrigatórias desde o primeiro período do curso. Algumas discrepâncias entre as duas línguas estrangeiras são notórias desde o momento da confecção da estrutura do curso, pois a disciplina de Espanhol constava de dois períodos com carga horária de 36h/a cada, totalizando 72h/a da grade do curso, em contraposição ao Inglês com quatro períodos somando uma carga horária de 144h/a. (SILVA JÚNIOR, 2010, p. 17)

Silva Júnior (2008) recupera que o primeiro concurso público para professor efetivo de Espanhol do Cefet/Rj acontece no ano de 2005 e motivado pela aprovação da Lei no 11.161/2005. O estudo informa que, naquele momento, a disciplina constava como obrigatória na grade curricular do 3 o ano do Ensino Médio e do curso Técnico de Turismo. Após o ano de 2007, a disciplina passou a ser implementada de forma gradativa em algumas turmas do Ensino Médio da instituição e somente em 2014 deu-se sua retirada da matriz curricular devido ao início do currículo do Ensino Médio Integrado.

O breve exposto até aqui demonstra que, desde a existência da antiga Escola Técnica Nacional, existe uma política para oferta de LE. Com a chegada do Espanhol, percebemos uma falta de igualdade entre as duas línguas no tocante à carga horária dos cursos de nível médio, tendo em vista que a Língua Inglesa continuou tendo uma maior carga horária e presença nos cursos técnicos. Inclusive, com a oferta do Ensino Médio Integrado, a Língua Inglesa permaneceu como disciplina obrigatória em todos os cursos e com a presença em dois anos de estudo. Já o Espanhol consta somente no curso Integrado de Turismo. Consideramos que a retirada da Língua Espanhola no currículo do Ensino Médio Integrado foi um contrassenso tendo em vista o conceito de educação politécnica e currículo integrado defendido por autores como Frigotto, Ciavatta e Ramos (2005).

A retirada do Espanhol da matriz curricular de quase todos os cursos Integrados do Cefet/Rj indica uma formação preocupada somente com a aplicabilidade dos saberes ao exercício futuro da profissão técnica, já que restringe o currículo a certos componentes curriculares. Essa visão é reducionista e impede o aprendiz de ser apresentado ao bem 
cultural de outras LE, uma vez que quanto maior a aproximação do aluno a diferentes LE, esse será levado a vivenciar, se confrontar, apreender o mundo e as pessoas, ou seja, ao que o pesquisador Almeida Filho (2012) aponta como papel da escola: "desentrangeirizar" o ensino de línguas.

A seguir, apresentamos a fundamentação teórica que conduziu nossa reflexão sobre as produções escritas de nossos alunos do Cefet/Rj.

\section{Fundamentação Teórica}

Para Bakhtin (2014), toda compreensão tem um caráter responsivo. Isso significa entender que "compreender um signo consiste em aproximar o signo apreendido de outros signos já conhecidos; em outros termos, a compreensão é uma resposta a um signo por meio de signos" (BAKHTIN, 2014, p.34). Orientando tal pensamento para o âmbito do ensino de línguas, podemos entender que aprender uma LE significa (re)construir conhecimento linguístico, caminho que já foi traçado na aprendizagem da LM. Desse modo, ao entrar em contato com uma LE o sujeito tenderá inicialmente a relacioná-la à sua LM. Bakhtinianamente, o ato de compreender consiste em assimilar esse novo signo da LE por meio de outro já conhecido - a LM - residindo aí a natureza responsiva da compreensão, na medida em que "responde" a um signo novo aproximando-o daquele que já lhe é familiar.

O teórico russo destaca a natureza sociointeracional dos signos, postulando que este processo molda as crenças e valores do sujeito, bem como suas identidades, atitudes e papel de ser social no mundo. Com isso, adverte-se que "a consciência adquire forma e existência nos signos criados por um grupo organizado no curso de suas relações sociais" (op. cit., p.36). A palavra em LM é percebida pela consciência de modo diferente do que o é em LE. Isso se dá uma vez que a palavra da língua nativa é vista como a "roupa familiar", faz parte da atmosfera em que se vive e se respira, ao contrário da palavra da LE, que é sentida com dificuldades. Em suma, de acordo com a concepção bakhtiniana, aprender uma LE demanda um processo ativo e responsivo que vai muito além da mera conversão e decodificação de palavras, pois a significação não se encontra encerrada no termo linguístico, tampouco na alma do falante ou interlocutor. Ela resulta do "efeito da 
interação do locutor e do receptor produzido através do material de um determinado complexo sonoro [...] Só a corrente da comunicação verbal fornece à palavra a luz da sua significação" (BAKHTIN, 2014, p.137).

Ancorados em uma perspectiva discursiva, entendemos o ensino/aprendizagem de línguas enquanto um processo de inscrição do sujeito da enunciação em discursividades da língua alvo (SERRANI, 1997). Isso significa considerar que não acreditamos em uma crença que reflita um estágio linear de que um dia o sujeito vá falar total e puramente a LE sem quaisquer influências da língua materna. Em lugar disso, compreendemos que as manifestações da LE são constitutivamente atravessadas por diferentes discursividades e regularidades enunciativas com as quais os aprendizes têm contato. Embasados na Análise de Discurso de linha francesa, entendemos que o aprendiz uma vez inscrito nas discursividades de uma LE, a manifestará com alguma característica peculiar, que tem a ver com a sua LM, fatores cognitivos, históricos, culturais e sociais. Sendo assim, consideramos que o sujeito poderá se inscrever na LE, usando-a numa situação comunicativa concreta, expressando-se em distintas variedades e registros, conhecendo aspectos da cultura estrangeira. Ao mesmo tempo, entendemos que existe uma tensão entre a identidade formada nas discursividades da LM e o processo de ressubjetivação, - problemático e perpassado por movimentos subjetivos de resistência - que se dá pelo contato com a LE. Em outras palavras, aprender uma LE requer um processo de identificação e ressubjetivação, que se inicia a partir do aumento do contato do aprendiz com textos produzidos na línguaalvo. Esse processo de (re)inscrição subjetiva nas discursividades da LE abriga diversas fases, mal-entendidos e não prevê uma chegada absoluta. Além disso, são ressaltadas questões afetivas, subjetivas e ideológicas envolvidas nas etapas do processo, o qual ocorre como um constante e contínuo deslocamento do sujeito da linguagem no (inter)discurso.

Ao pensar a relação entre LM, LE e subjetividade, no caso específico do português/LM e do espanhol/LE no contexto brasileiro de ensino/aprendizagem, Celada (cf. 2004, 2008) alude às chamadas "antecipações imaginárias", por parte dos sujeitos aprendizes, que dizem respeito à circulação de imaginários que se relacionam a ideia de que o espanhol é "uma língua correta, detalhista, redundante [...] rebuscada, formal" (CELADA, 2004, p.45). 
Essa série de imagens estereotipadas conduz ao imaginário fortemente cristalizado entre brasileiros os quais a autora resume mediante as sequências "espanhol - língua parecida - língua fácil”. A formulação desse imaginário se vincula ainda à posição simbólica definida e defendida pela teórica que acaba por sintetizar todos esses imaginários anteriores: a imagem do espanhol para brasileiros como uma língua que se adquire espontaneamente. Essa imagem é chamada de "ilusão de competência espontânea" (cf. CELADA, 2002, 2004), já que "el brasileño pensó como una extensión espontánea de la propia" (CELADA, 2004, p.43).

Em Celada e Payer (2016), as estudiosas pensam tais antecipações enquanto identificações imaginárias, que se referem a apropriações de conceitos lacanianos já mobilizados por muitos estudiosos do discurso (cf. SERRANI, 1997). Ditas identificações imaginárias, assim como as antecipações, podem ser entendidas como o funcionamento de uma idealização, de um estereótipo. Dessa forma, segundo as pesquisadoras, "o fato de que um estudante brasileiro diga que o espanhol é uma 'língua correta' [...] pode levá-lo a uma transposição de formas do português da escola (como uma língua escrita que nunca atingiu) e que não condizem com formas possíveis no funcionamento da língua espanhola" (CELADA \& PAYER, 2016, p.34).

Essas antecipações imaginárias podem proporcionar uma ilusão de comunicação, na medida em que dão corpo a gestos que implicam o deslizamento de uma posição simbólica formada na subjetividade da língua materna do brasileiro. Como exemplo, recorremos a excertos de produções escritas em espanhol produzidas por estudantes brasileiros extraídos de Celada (2004, p.46):

(1) Señor Rossi, ipor Dios! ¿Qué hiciste? No estás en un restaurante o en tu casa para que sirvas fiambres. ¿No sabes tú que para cada situación hay maneras diferentes de tratar a las personas. Tienes que adaptarte al ambiente de una joyería. ¿Piensas que a todos los clientes les gusta comer en una joyería? Estamos en un establecimiento de alto nivel, por lo tanto portate como una persona de alto nivel. Les sirva café.

A estudiosa observa no trecho exibido acima a alternância de tratamento entre as formas de terceira (señor) e de segunda pessoas (tú), além do deslocamento do pronome (le) para o começo da frase em "Les sirva café", uma vez que só seria possível em espanhol o 
emprego da ênclise em razão da presença da forma imperativa ("Sírvales café"). Diante disso, entendem-se as produções escritas como marcas de deslizamentos de posições simbólicas que o brasileiro projeta no campo de sua língua materna. Em outras palavras, produções como "les sirva café" são compreendidas como um deslizamento de uma posição sujeito característica da oralidade do português brasileiro (CELADA \& PAYER, 2016), que costuma mesclar, nas interlocuções orais, formas de segunda e terceira pessoas, no intuito de "evitar a abrupção com o outro, de se aproximar do outro, de 'deixar o outro chegar'" (CELADA, 2008, p.158). Além disso, essas antecipações podem ainda guardar relação com imaginários que concebem o espanhol como "uma língua correta, detalhista, redundante, complicada, rebuscada, formal, mandona" (CELADA, 2004, p.45), conforme já aludimos anteriormente de maneira breve. Este estereótipo se vincula ao fato de que a língua espanhola imprime uma ressonância ao brasileiro de uma "língua escrita", de "la escritura modelar y normativa de la cual la escuela es mantenedora y lo afecta en la contradicción constitutiva que su subjetividad soporta por abrigar la relación de no continuidad que entre escritura y oralidad se produjo en Brasil, como efecto de un proceso de colonización" (idem, p.48).

Apresentamos outro exemplo extraído de Celada e Payer (2016, p. 34) que também parece contribuir para o entendimento bem como funcionamento dessas antecipações imaginárias. Observemos as produções a seguir:

(2) ¿Me presentas a tu compañera? Te la presento.

(3) ¿Me presentas a tu compañera? Presento-lo.**

O exemplo (3) elucida uma resposta ao enunciado “¿Me presentas a tu compañera?” que não seria possível em língua espanhola. Dessa forma, isso resulta de uma projeção do aprendiz brasileiro de entender essa língua estrangeira como "correta" e "difícil", após a antecipação de que ela seria "fácil", e assim lançar mão de formas condizentes com este imaginário de "língua correta, da escrita, detalhista" identificando a LE com a escrita padrão da língua materna, através de um deslizamento de uma posição simbólica. Assim, esta forma destacada ("presento-lo") se inscreve em uma memória de escrita em português e materializa um gesto para dar conta de um imaginário "de uma língua inatingível, a mercê 
de sentidos instaurados em cena da escrita escolar, que ressoam na relação que um aprendiz brasileiro passa a travar com a língua espanhola" (idem, p.34).

As antecipações são entendidas como movimentos transferenciais que demandam identificações simbólicas, as quais o brasileiro identifica o espanhol enquanto uma língua "correta, detalhista, da escrita, redundante, pronominal". Salientamos, entretanto, que tais antecipações não são abarcadas enquanto meras transferências de fragmentos da língua materna, uma vez que se entende estar acontecendo neste processo um movimento ou uma agitação nas redes da memória do sujeito no que tange ao (seu) processo de inscrição subjetiva nas redes da memória da língua-alvo, neste caso, a língua espanhola. A LE é, dessa forma, interpretada como uma função que atravessa o campo de uma subjetividade, a fim de que esta língua aconteça no sujeito, de acordo com o pensamento orlandiano (CELADA, 2008). Em suma, saber algo através de uma língua pressupõe que no campo de uma subjetividade aconteçam identificações com saberes interdiscursivos.

Diante do exposto, podemos perceber que se torna impossível refletir acerca do processo de ensino/aprendizagem de uma LE, sem levar em consideração a LM. A francesa Christine Revuz, em seus estudos em Psicanálise - categoria mobilizada em muitos estudos em Análise de Discurso - defende a perspectiva de que, durante o processo de aprendizagem de uma LE, as bases da estruturação psíquica são solicitadas e, portanto, a primeira língua: “(...) o exercício requerido pela aprendizagem de uma língua estrangeira se revela tão delicado porque (...) solicitam-se as bases mesmas de nossa estruturação psíquica, e com elas aquilo que é, a um mesmo tempo, o instrumento e a matéria dessa estruturação: a linguagem, a língua chamada materna" (REVUZ, 1998, p.217).

No que tange ao entendimento do alunado em aulas de leitura em LE, Marisa Grigoletto (2010) observou que a construção de significação nestas aulas está, tradicionalmente, associada à tradução item a item:

[...] concepção enfatizada é a de que a atividade de leitura em LE está associada à atividade de tradução; o entendimento estaria necessariamente ligado à tradução das partes ou do todo. De toda forma, a ênfase continua a recair sobre as palavras, em uma tarefa de tradução das palavras desconhecidas [...] (GRIGOLETTO, 2010, p.105). 
Esse pensamento reflete uma postura de ensino/aprendizagem tradicional, em que alunos se comportam como sujeitos passivos e recebedores do saber, este detido tãosomente pelo sujeito professor. Tal visão acaba por ensejar uma educação homogeneizante e reduzida a uma única maneira de se abordar o texto, que se refere à instituída pelo professor, solidificando-se assim as já desiguais e naturalizadas relações de professor/ativoalunos/passivos. Chama-se atenção, dessa forma, para o imaginário dos discentes sobre o que seriam aulas de LE: decodificação de palavras, calcadas na tradução termo a termo, buscando-se converter os vocábulos de uma LE para os da LM, de forma tradicional e linear. Podemos relacionar tal postura à defendida por Revuz (1998) no que concerne aos aprendizes que evitam distância em relação ao eu da LM, recusando todo contato direto com a LE. Diante disso, estes aprendizes somente podem compreender um enunciado em LE se cada termo for traduzido em LM, criando uma visão de que o sentido deve permanecer "escrupulosamente limitado às fronteiras das palavras da língua materna" (REVUZ, 1998, p.224).

O exposto acima será retomado em nossa análise dos dados gerados como forma de responder ao objetivo proposto para esta reflexão de caráter teórico-prático.

\section{Proposta Metodológica}

A fim de lançarmos um olhar analítico em direção à relação entre o Português/LM e o Espanhol/LE, acompanhamos aulas de Espanhol de alunos de 10 ano de Ensino Médio, no campo de estágio obrigatório, referente à disciplina "Prática de ensino", que faz parte da grade curricular do curso de licenciatura em Letras Português-Espanhol. Os autores deste artigo, a partir de seus âmbitos como professor regente das aulas e estagiário/professor em formação, respectivamente, construíram conhecimento em conjunto através das vivências e práticas experienciadas no contexto supracitado.

O corpus de nossa pesquisa foi gerado por meio de duas questões integrantes da prova bimestral, além de algumas perguntas orais realizadas com alguns alunos após a realização da prova. Adquirimos 33 produções escritas e 13 áudios de gravação, que abrangem depoimentos orais de 16 alunos.

LínguaTec, Bento Gonçalves, v. 3, n. 5, p. 51-68, jun. 2018. 
As questões se referem a duas produções escritas em Espanhol. Na primeira questão, os discentes deveriam produzir um texto a partir de duas imagens de personalidades do mundo hispânico, ao passo que, na segunda, deveriam produzir em torno da imagem de uma família. Em ambas as redações, os alunos deveriam descrever as pessoas envolvidas na cena, utilizando os vocabulários estudados em aulas, tais como, graus de parentesco, aspectos físicos, aspectos psicológicos/ de caráter, roupas e cores. A tipologia enfocada foi a descrição em função de esta ser a tipologia enfatizada no programa do 1o ano da instituição campo de estágio/ pesquisa.

Os discentes não receberam nenhum tipo de auxílio por parte do professor, nem consulta a nenhum material, uma vez que se tratava da avaliação bimestral. Com isso, acreditamos que as produções escritas analisadas exprimem resultados mais espontâneos no que tange ao processo de ensino/aprendizagem do Espanhol. Salientamos, ainda, que as questões do exame foram desenvolvidas em parceria entre a estagiária e o professor regente. Diante disso, o corpus obtido foi analisado a partir do quadro teórico desenvolvido e exposto na seção anterior.

\section{Análise de Dados}

Apresentamos a continuação os enunciados, extraídos da prova bimestral, que oportunizaram as produções escritas as quais examinamos, com a finalidade de promovermos uma discussão em torno do ensino/aprendizagem de Espanhol considerando a influência do Português/LM.

Questão 1:

Las imágenes a continuación presentan fotografías de dos personalidades hispánicas (Anahí y Lionel Messi). Descríbelos físicamente utilizando las estructuras descriptivas y el vocabulario estudiado en clase. Debes describirlos lo más completo posible e imaginar los colores. Utiliza, por lo menos, 5 características descriptivas para cada imagen.

Questão 2:

Redacta un pequeño texto, en español, en el cual debes establecer una relación familiar para las personas de la imagen. Descríbelas utilizando el vocabulario estudiado en 
clase (rasgos físicos y de conducta, los grados de parentesco y las ropas y colores). Todas las personas de la imagen deben constar en tu texto.

Originalmente, na prova da qual foram extraídas, as questões estavam acompanhadas das respectivas imagens. Na primeira, foram disponibilizadas as figuras de duas personalidades do mundo hispânico, a saber, a atriz e cantora Anahí e o jogador de futebol Lionel Messi. Na segunda, ofertava-se uma figura com várias pessoas, por meio da qual foi pedido aos discentes que criassem e descrevessem relações familiares entre os envolvidos na cena, utilizando os conteúdos abordados em aula (adjetivos, verbos, conectivos e vocabulários de substantivos), gerando, desse modo, um texto. Além dessas redações, examinamos os depoimentos gravados de alguns alunos cujas perguntas motivadoras exibimos a seguir:

1) Você sentiu dificuldades de escrever em espanhol? Os conteúdos linguísticos estudados em aula ajudaram na hora de montar o texto?

2) Que estratégia você utilizou: escreveu primeiro em português e depois em espanhol, ou já escreveu diretamente em espanhol?

No tocante à pergunta 2, a maioria dos alunos disse ter escrito direto em Espanhol, justificando "que já pensaram direto nessa língua". Desse modo, destacamos dois alunos, a modo de exemplificação:

Aluno 1: "Pensei direto em Espanhol porque para você escrever em uma língua você tem que pensar direto nessa língua [...] para você aprender uma língua você tem que aprender direto nela".

Aluno 2: "Pensei em Espanhol já [...] escrevi direto em Espanhol sem passar pelo português porque já tinha estudado o vocabulário".

Dos 16 alunos que gravaram depoimentos orais: 9 disseram pensar diretamente em Espanhol; 3 disseram pensar "algumas coisas em Português, mas a maioria em Espanhol"; 3 disseram ter pensado em Português e traduzido para o Espanhol e 1 disse ter pensado nos dois idiomas, sem discriminá-los. Sendo assim, a maioria dos alunos deu respostas que se coadunam aos dois modelos expostos acima, sempre argumentando que "já pensaram direto em Espanhol", "sem utilizar o português", porque "é outro idioma" e manifestando assim diversos imaginários do senso comum que vem à tona quando se fala em ensino e 
aprendizagem de línguas. Examinando suas produções sinalizamos nas linhas seguintes, diversas palavras e expressões que indiciam que a presença da $L M$, no caso o português brasileiro, não se encontra tão distante assim como manifestam os (auto)discursos discentes:

(1) Juan es lo más viejo [...] Darío es lo hijo más viejo, es calvo y tiene la personalidad semelhante a de su padre. Vale es una niña baja, tiene el pelo corto y negro y es semelhante a su abuela.

(2) João es primo de Pedro, tiene lo pelo loro y corto [...] Anahí es una mujer joven [...] Su pelo es loro.

(3) [...] la idosa de pelo gris [...] que es mujer de lo idoso [...] Lo chico que es padre de la mujer [...] que es mujer de lo joven [...].

(4) Lo abuelo tiene pelos blancos [...].

(5) Beatriz es una niña muy alegre de pello loro [...] Anahí es una mujer delgada. Tiene el pelo loro [...].

(6) Lo padre tiene piel blanca.

(7) Los idosos en la imagen, Pablo y Rosa, son granpadre y granmadre de Juan, Carlos y Antonio. (...) Es una mujer de estatura mediana, tiene ojos vierdes.

(8) Yo soy lolanda, tiengo diez años.

(9) Un niño de ojos vierdes y pelo niegro.

(10) Maria eres hija de Miguel y eres rubia [...] Messi es un chico bajo [...] Ello no tiene barbilla.

(11) Esteban es un hombre de alta estatura y cuerpo fuerte. Elle es padre de Nita y Nico, que son hermanos y [...] son muy espertos [...] Elles tienen como abuelos Sofía y José.

(12) Messi [...] es bajo e un poquito regordeto [...] Lleva una blusa de su time de colores roja y azul.

(13) Esta es uma família muy feliz (...) José e Julia tienen que cuidar de su sobriña, una menina muy linda e carismática [...].

(14) Anahí es una mujer joven y es alta. Tiene el pelo ondulado y ruibo [...] Anahí está en la fotografia con una fauna azule [...]. 
(15) Anahí possue pello rojo, ojos grandes y azuis, bojejas suaves, piernas delgadas y dientes medios y brancos.

(16) [...] os dois son hermanos y tienen pelo rubio [...] Tiene el pelo rubio y es muy engraçado.

(17) Paula és nora de Maria pois su marido és filho de João e Maria. Caio és primo de Felipe e Gustavo [...] Os três niños son jovens de estatura media.

(18) Lionel Messi és um hombre joven [...] Tiene pequeños ojos pretos e una barbilla quadrada.

(19) El encontro de la família acontece todo sábado (...) El padre es muy tímido [...] su mujer es o oposto, muy falante [...] una abuela e un abuelo que são Pedro y Maria.

(20) Los domingos Juan y Carlos llevan sus respectivos hijos para encontraren los abuelos.

(21) Lo padre és muy bueno para todos [...] Lo abuelo gusta de ler para sus netos y también gusta de ser sogro. Usa siempre blusas largas y zapatos negros, como su gienro [...] Messi tiene pelos negros (...) és jugador del fútbol y usa una blusa del time que juga.

(22) Carmem e Júlio, son casados a 40 años, su hijo Juan fue les visitar con su familia, sua esposa Letícia e sus hijos Luca e Felipo.

A LM, como podemos perceber, desempenha um forte papel nos trechos selecionados. Conforme assinala Bakhtin (2014), a compreensão é responsiva, o que faz com que os alunos respondam (n)a LE mobilizando a LM, isto é, a fim de produzirem compreensão, relacionam, de maneira inconsciente, os signos da $L E$, aos de sua $L M$, uma vez que a LM é a "roupa familiar", ou seja, a palavra em língua nativa não é habitualmente percebida, uma vez que faz parte da atmosfera que se vive e se respira, ao mesmo tempo que se manifesta como o instrumento e a matéria da estruturação psíquica, de acordo com as formulações tecidas por Revuz (1998). Pautando-nos em Serrani (1997), entendemos que os alunos enfocados se encontram em um processo inicial de inscrição subjetiva nas discursividades da LE, o que faz com que os movimentos subjetivos sejam fortemente atravessados pelas discursividades da LM, dando lugar a processos de enfrentamento e 
tensão entre as discursividades da LM e as novas, que começam a ser desenvolvidas devido ao contato contínuo com a LE.

Para examinarmos os fragmentos acima, recorremos às chamadas antecipações imaginárias aludidas por Celada (2004). Nos trechos que compreende o intervalo (1)-(6), podemos perceber produções geradas pelo contato Português-Espanhol que se referem a termos como "lo" (como artigo definido) e "loro". Essas formas intermediárias - que não são observadas nem em português nem em Espanhol - podem estar indiciando um funcionamento de uma antecipação imaginária por parte dos alunos brasileiros de Espanhol. Ao gerarem a forma "Io", por oposição ao artigo feminino "la", os aprendizes podem estar se guiando por sua LM - que apresenta os artigos " $a$ " e "o" - e assim se filiando ao imaginário do Espanhol de "língua fácil", "língua parecida com o Português", produzem "lo" na condição do masculino de "la". A forma "loro" também parece indicar essa mistura das duas línguas efetuada através de uma antecipação imaginária que rearranja os termos da LM (louro/loiro), transformando-os em "loro", talvez pelo imaginário do Espanhol que costuma monotongar os ditongos "ou" do português, como em "outro > otro; pouco > poco", só para citar alguns exemplos, levando, assim, os aprendizes a produzirem a forma "loro". A mesma hipótese também serve para os casos de ditongação, como nos exemplos (7), (8) e (9), em que podemos observar uma transformação de "e > ie", visto que formas linguísticas existentes nos léxicos das línguas como "velho > viejo" podem motivar, através de uma antecipação imaginária dos discentes, as formas "negro > niegro; genro > gienro e tenho > tiengo", conforme podemos visualizar nos fragmentos supracitados. No fragmento (7) há as formas "granmadre" e "granpadre", em que o radical gran- parece buscar influência na Língua Inglesa que apresenta as formas "grandmother" e "grandfather" para "abuela" e "abuelo", respectivamente. O exemplo (10) ao apresentar as formas "eres" evidencia uma nítida influência do português, posto que ao invés de empregar a forma do Espanhol de terceira pessoa ("es"), que em português é uma forma de segunda pessoa (és), o aprendiz produz "eres", que é uma forma de segunda pessoa em Espanhol.

As antecipações imaginárias continuam se materializando através de variadas hipóteses, como em (10), (11), (12), (13) e (14), em que podemos nos atentar para produções variantes como "ello", "elle" e "elles" em lugar do artigo masculino él/ellos; a 
forma "regordeto" em lugar de "regordete" em oposição à forma de feminino "regordeta"; a forma "sobriña", que usa a letra "ñ" do Espanhol numa tentativa de correspondência ao termo em português ("sobrinha"); e, por fim, a forma "ruibo" que evidencia uma nítida mistura de línguas, ao produzir o que seria "pelirrojo" em Espanhol, lançando mão de uma antecipação imaginária que rearranja o termo da LM ("ruivo") ao da LE ("ruibo"), já que em Espanhol não se realiza o som de "v". O imaginário de similaridade do Espanhol ao português que resulta em uma língua fácil continua tomando corpo gerando as formas "fauna azule" (14), para o que seria "falda azul"; "bojeja" (15), por aproximação à "bochecha" em português e por aí vai.

Além das antecipações imaginárias que ganham corpo nos itens lexicais da LE, ainda podemos observar produções que supostamente estão escritas apenas em Espanhol e que manifestam influência do Português. É o caso do trecho (20), em que parece ocorrer uma certa influência da LM, uma vez que em Espanhol teríamos uma produção como " Los domingos. Juan y Carlos llevan a sus respectivos hijos para encontrar a sus abuelos", com a presença da preposição "a" regendo complemento direto preposicionado diante do traço [+ animado], além da não conjugação da forma de infinitivo. Em (21), percebemos um caso análogo ao anterior, posto que o verbo "gustar" do Espanhol aparece conjugado de maneira similar ao "gostar de" em português. Em (22), notamos a produção "a" em lugar de "hace" que indicia um desvio da norma padrão em língua materna que se transferiu para a língua estrangeira. Além disso, chamamos a atenção para a produção "Juan fue les visitar" designar um funcionamento de uma antecipação imaginária através do uso do clítico "les". Ao produzir o clítico, o aprendiz parece se filiar ao imaginário do Espanhol enquanto língua pronominal, formalista, redundante, conforme sinaliza Celada (2004), e assim acaba fazendo um uso desviante da norma padrão do Espanhol, já que o esperado neste caso de perífrase verbal seria algo como "Juan les fue visitar" ou "Juan fue visitarles". Além dos casos mencionados, podemos visualizar um massivo atravessamento de itens lexicais da própria LM de maneira direta, como em "semelhante" (1), "brancos" (15), "os dois" e "engraçados" (16), "nora", e "filho" (17), "encontro" e "acontece" (19), dentre outros.

De acordo com o exposto, entendemos que as produções em LE foram continuadamente atravessadas pela LM, apesar dos (auto)discursos dos alunos de que "não 
utilizaram o português" (e/porque) "já pensaram direto em Espanhol". Diante desse imaginário, podemos recorrer ainda às considerações postuladas por Christine Revuz (1998), quando a estudiosa argumenta que, para a constituição de uma subjetividade em uma LE, são solicitadas simultaneamente três esferas existenciais básicas. Uma delas diz respeito à relação do sujeito com ele próprio, isto é, alude à afirmação do eu enquanto sujeito que se autoriza a falar em primeira pessoa. Já outra esfera se refere à relação do sujeito com o saber, ou seja, concerne ao componente que se relaciona à aprendizagem de regras linguísticas e regularidades enunciativas, em suma, refere-se à língua na condição de objeto de conhecimento. Em síntese, relacionando este pensamento aos nossos dados, podemos compreender que por um lado os alunos analisados demonstraram que estão mobilizando a esfera subjetiva concernente à afirmação de um eu em LE, pois defendem que já pensam diretamente em Espanhol e que não "passaram pelo português", assumindo, assim, um (auto)discurso de proximidade com a língua. Por outro lado, contudo, evidenciam que ainda estão em processo de mobilização da esfera relativa às regularidades linguístico-discursivas, realizando movimentos de inscrição subjetiva nas discursividades da LE que se encontram em estágio muito inicial, sendo fortemente atravessadas pela LM.

Com relação à pergunta 1, que indagava se os aprendizes haviam sentido dificuldade de produzir em Espanhol, muitos alunos responderam que não sentiram dificuldades, pois "já conheciam os vocabulários e haviam estudado os conectivos" de modo que "haviam conseguido amarrar o texto". Este tipo de resposta remete a imaginários que acabam por conceber as línguas apenas em sua dimensão lexical, calcada em uma tradução linear de palavras, numa busca incessante e esgotante de termos, conforme atesta Grigoletto (2010). Acreditamos que essas posturas também desvelam antecipações imaginárias do que seria o ensino/aprendizagem de línguas, tanto materna quanto estrangeira, mas que talvez se mostre mais problemática justo nas aulas de LE: uma visão linguística reduzida ao sistema lexical, ao domínio do vocabulário. Salientamos que essa concepção não reflete a perspectiva de trabalho em sala defendida pelo professor regente e equipe de estagiários em formação, tratando-se, contudo, de uma visão quase cristalizada no imaginário de qualquer aprendiz de LE. Tal pensamento, no caso do Espanhol, pode ter consequências 
mais expressivas, em virtude do mito de língua fácil e da ilusão de competência espontânea, devido à proximidade tipológica entre as línguas.

\section{Considerações Finais}

A presença da LE no contexto da educação profissional não deve ser entendida meramente como um saber que será necessário para uso no desempenho da atividade profissional futura, mas sim deve ser um conhecimento que possibilite que o sujeito se inscreva em diferentes discursividades e se permita enxergar como usuário da LE, sendo capaz de adicioná-la ao seu repertório linguístico.

A reflexão proposta com este artigo demonstra uma relação de parceria entre o professor regente, a estagiária em formação e os discentes, no contexto de uma instituição tecnológica do Rio de Janeiro que ofertava de modo obrigatório o ensino de Espanhol, como uma forma de avaliar resultados do processo de aprendizagem da LE. Defendemos a premissa de que a LM, apesar de a produção escrita e as falas dos próprios alunos demonstrarem o oposto - contribui para a nova inscrição discursiva na LE. Os excertos apresentados expressam que os alunos acabam não se dando conta das hibridizações linguístico-discursivas que geram no momento da produção escrita, o que, em termos bakhtinianos, é perfeitamente natural, uma vez que é na LM "e por meio dela que ocorre o primeiro despertar da consciência" (BAKHTIN, 2014, p. 111). De acordo com o filósofo russo, o sujeito identifica sua língua nativa como "uma roupa familiar" e assim ao entrar em contato com uma LE processa transferências linguísticas de modo, muitas vezes, involuntário.

Os dados gerados apontam para a necessidade de se refletir junto aos alunos a respeito do processo de aprender uma nova LE. Compartilhar os motivos pelos quais um sujeito aprende uma língua e como isso pode ser possível, tende a contribuir para os modos como o discente será capaz de lidar com certas crenças em relação à aprendizagem do vocabulário e aspectos linguísticos, por exemplo, visando uma maior autonomia para o desenvolvimento de destrezas discursivas e sociais, tão importantes para a educação linguística e crítica dos aprendizes. Nessa direção e perspectiva de trabalho, pautamos nossa 
defesa pela retomada do ensino de Espanhol na educação profissional como mais uma língua para interação sócio discursiva no mundo.

Devido à ausência de uma política plural para as LE no Cefet/Rj, desde a implementação do Ensino Médio Integrado, sabemos que experiências pedagógicas como a relatada neste artigo estão ameaçadas de continuidade. Soma-se a isso a realização de uma proposta de ensino diferenciada na educação profissional ao priorizar o contato com a Língua Espanhola por meio de gêneros discursivos variados de nosso contexto sóciohistórico e um trabalho integrado com as habilidades linguísticas, destacando as diferentes tipologias textuais e culturas e espaços geográficos discursivos da LE. Os gêneros trabalhados, os temas sociais elencados e a reflexão linguística na língua alvo não se limitam simplesmente ao contexto do futuro campo profissional de atuação do aluno, mas sim perpassam discussões e problematizações pertinentes a um jovem estudante da Educação Básica.

Recentemente, outro fator arbitrário foi a aprovação da reforma do Ensino Médio por meio da Lei no 13.415/2017, que, entre as diversas alterações, modifica o teor da LDB no 9394/1996, altera a oferta do Ensino Médio e impõe novamente um currículo monolíngue na Educação Básica, obrigando a oferta do ensino da Língua Inglesa como única LE do currículo. Essa concepção vai à contramão do que o mundo moderno exige: um sujeito capaz de se comunicar e interagir em diferentes línguas e culturas. Além disso, essa (contra)reforma não dialoga com umas das premissas da nossa Constituição Brasileira (BRASIL, 2011), cujo texto do Parágrafo único do Artigo quarto preconiza a necessidade de nosso país buscar "[...] a integração econômica, política, social e cultural dos povos da América Latina, visando à formação de uma comunidade latino-americana de nações". Portanto, como promover tal integração se os documentos vigentes de orientação curricular do país retiram o direto de o aluno estudar a Língua Espanhola na Educação Básica? Também vale ressaltar que a Lei no 13.415/2017 também não valoriza o modelo atual de formação do Ensino Médio Integrado proposto pelos Institutos Federais e Centros Federais de Tecnologia de nosso país. As novas propostas podem ser consideradas como retrógadas porque defendem uma perspectiva de formação voltada unicamente para o mercado de trabalho, em especial, a iniciativa privada. 
Pelo exposto, fica evidente que o aluno da Educação Básica, seja regular ou profissional, sai perdendo com a saída do Espanhol do currículo. E por quê? Tomando como parâmetro a proposta curricular do Cefet/Rj para o Ensino Médio, esse aprendiz deixa de (a) refletir sobre as múltiplas práticas contextualizadas da linguagem, (b) (re)construir seu senso crítico para maior engajamento social, (c) revisitar diálogos com demais culturais através de uma assimilação de conceitos como identidade, alteridade e interculturalidade, (d) fomentar práticas com a linguagem voltadas para o trabalho e a cidadania, (e) exercitar práticas interdisciplinares e integradoras entre diferentes componentes curriculares, (f) ponderar temas e estruturas linguístico-discursivas tanto em língua materna (LM) quanto em LE. Ou seja, a política linguística atual pautada em um ensino monolíngue - do Cefet/Rj e da atual (contra)reforma do Ensino Médio - priva e reduz as possibilidades do aluno ter acesso à outras línguas e culturas no currículo da educação profissional. A realidade atual pode aumentar ainda mais a dualidade entre classes na sociedade e intensificar o hiato entre a educação pública e privada em nosso país.

\section{REFERÊNCIAS}

ALMEIDA FILHO, J. C. P. Quatro estações no ensino de línguas. Campinas: Pontes Editores, 2012.

BAKHTIN, M./ VOLOCHINOV, V. N. Marxismo e Filosofia da Linguagem. 16ạ edição. São Paulo: Hucitec, 2014.

BRASIL. Lei $n$ o 13.415, de 16 de fevereiro de 2017.

- Constituição da República Federativa do Brasil. Brasília, STF/ Secretaria de Documentação, 2011.

- Orientações Curriculares para o Ensino Médio: linguagens, códigos e suas tecnologias. Brasília: SEB/MEC, 2006.

CELADA, M. T. Lengua extranjera y subjetividad - apuntes sobre un proceso. Estudos Linguísticos. São Paulo, Campinas, 2004. Disponível em: <http://www.gel.org.br/estudoslinguisticos/edicoesanteriores/4publica-estudos2004/4publica-estudos2004-pdfs-mesas/lengua_extranjera.pdf> 
. O que quer, o que pode uma língua - Língua estrangeira, memória discursiva, subjetividade. Letras. Universidade Federal de Santa Maria, 2008. Disponível em: <http://cascavel.ufsm.br/revistas/ojs-2.2.2/index.php/letras/article/view/11985/7399>.

CELADA, M. T.; PAYER, M. O. Sobre sujeitos, língua(s), ensino. Notas para uma agenda. In: CELADA, M. T.; PAYER, M. O (Org) Subjetivação e processos de identificação. Sujeitos e línguas em práticas discursivas - inflexões no ensino. Campinas, SP: Pontes Editores, 2016, p. 17-41.

CIAVATTA, M. \& SILVEIRA, Z. S. Celso Suckow da Fonseca. Recife: Fundação Joaquim Nabuco, Editora Massangana, 2010.

FRIGOTTO, G; CIAVATTA, M.; RAMOS, M. Ensino médio integrado: concepções e contradições. São Paulo: Cortez, 2005.

GRIGOLETTO, M. Processos de significação na aula de leitura em língua estrangeira. In: CORACINI, M. J. R. F. (org.). O jogo discursivo na aula de leitura: língua materna e língua estrangeira. 3a edição. São Paulo: Pontes, 2010, p. 103-110.

NORTE, A. L. Internacionalização do Cefet/Rj: tendência mundial, crescimento e protagonismo discente. In: Tecnologia \& Cultura, $\mathrm{n}^{\circ} 23$, ano 16 (jan/jun. 2014). Rio de Janeiro: Cefet/Rj, 2014, p. 7-14.

REVUZ, C. A língua estrangeira: entre o desejo de um outro lugar e o risco do exílio. In: SIGNORINI, Inês (Org.). Lingua(gem) e identidade. São Paulo: Mercado de Letras, 1998, p. 213-230.

SERRANI, S. Formações discursivas e processos identificatórios na aquisição de línguas. DELTA - Revista de Documentação de Estudos em Linguística Aplicada, n. 1, vol.13, [versão online], São Paulo: fevereiro, 1997.

SILVA JÚNIOR, A. F. O ensino de espanhol num centro federal de educação tecnológica: articulando saberes. Revista FACEVV, v.5, 2010, p. 13-22.

- A trajetória do espanhol e seu ensino no curso técnico de Turismo do Cefet/Rj. Actas del Simposio Internacional de Didáctica del Español como lengua extranjera. Rio de Janeiro: Instituto Cervantes, 2008, p. 79-87. Disponível em: < https://cvc.cervantes.es/ensenanza/biblioteca ele/publicaciones centros/PDF/rio 2008/08 dasilva.pdf>.

Data de submissão: 15/04/2018. Data de aprovação: 08/05/2018. 